\section{Colored Bell Pepper Yields from Cultivars Grown in High Tunnels in Northern New England}

\author{
Rebecca Grube Sideman ${ }^{1}$
}

ADDITIONAL INDEX wORDs. greenhouse, season extension

SumMary. High tunnels can facilitate production of ripe colored bell peppers (Capsicum annuum) in locations with short growing seasons by extending the length of the growing season and protecting fruit from biotic and abiotic stressors. We grew 10 cultivars of bell pepper over 3 years in a high tunnel in Durham, NH. Yields of marketable colored fruit ranged from 1576 to $2285 \mathrm{~g} /$ plant in 2015, from 1194 to $1839 \mathrm{~g} /$ plant in 2016, and 1471 to $2358 \mathrm{~g} /$ plant in 2017 . Significant differences in marketable yield among cultivars existed only in 2015 and 2017 . Of the 10 cultivars evaluated, those developed for controlled environments produced greater marketable yields than those developed for production in the field or unheated tunnels $(P<\mathbf{0 . 0 0 0 1})$. The seasonal production patterns were similar among cultivars in all 3 years: a single peak in production occurred between 159 and 175 days after seeding, followed by much lower but steady production until frost ended each growing season. Our results demonstrate that reasonable yields of colored bell peppers can be produced in high tunnels in locations with short growing seasons. We suggest that further work may be needed to identify optimal pruning and canopy management strategies to maximize yields and fruit quality.

$\mathrm{H}$ igh tunnels are portable, greenhouse-like structures with a single or double layer of plastic that may or may not have heat, power, or ventilation (Wells, 1996). In this article, the term "high tunnels" is used to refer to greenhouses without supplemental heating.

Although tomato (Solanum lycopersicum) remains the most widely grown high tunnel crop in northern New England, bell pepper (Capsicum annuum) is also commonly grown in high tunnels (Carey et al., 2009; Fitzgerald and Hutton, 2012). In fact, a recent survey of high tunnel producers in the region found bell

Received for publication 14 Jan. 2020. Accepted for publication 6 Mar. 2020

Published online 6 April 2020.

${ }^{1}$ Department of Agriculture, Nutrition \& Food Systems, University of New Hampshire, 38 Academic Way, Durham, NH 03824

I thank John McLean, Evan Ford, Kyle Quigley, David Goudreault, and Luke Hydock for technical assistance. I also thank Kaitlyn Orde and Brent Loy for providing thoughtful reviews of the draft manuscript.

Partial funding was provided by the New Hampshire Agricultural Experiment Station under U.S. Department of Agriculture National Institute of Food and Agriculture Hatch Project NH00635. This is Scientific Contribution No. 2842.

R.G.S. is the corresponding author. E-mail: becky. sideman@unh.edu.

This is an open access article distributed under the CC BY-NC-ND license (https://creativecommons.org/ licenses/by-nc-nd/4.0/).

https://doi.org/10.21273/HORTTECH04577-20 pepper to be the second most popular crop grown in tunnels (Sideman et al., 2016). Growers have reported greater yields and gross income for bell peppers grown in high tunnels compared with open field conditions (Fitzgerald and Hutton, 2012). This may be because tunnels lengthen the potential harvest season for green bell peppers and also facilitate production of ripe colored fruit, which is difficult in field conditions when the growing season is short.

In the northeastern United States, growers commonly use the same cultivars for field and high tunnel production, whereas in other regions of the world, cultivars selected specifically for greenhouse or high tunnel conditions are used. In 2015, seed suppliers in the United States began to offer and promote bell pepper cultivars that had been developed specifically for high tunnel and greenhouse production systems.
Several extension reports describe 1-year high tunnel bell pepper cultivar trials conducted in Iowa (Taber et al., 2009), Indiana (Maynard and Calsoyas, 2015), New York (Reid et al., 2011), and Pennsylvania (Bogash and Elkner, 2011). In northern New England, bell pepper cultivars have been compared under field conditions (Hutton and Handley, 2007), but performance of bell pepper cultivars in the high tunnel environment has not been described in the peerreviewed literature.

This article reports the results of a 3-year study comparing bell pepper cultivars grown in high tunnel conditions. Specifically, we sought to compare colored fruit yields for several cultivars and to determine whether cultivars bred for greenhouse and tunnel conditions would outperform standard field cultivars (in terms of yield or production season) when grown in the high tunnel environment.

\section{Materials and methods}

All cultivars evaluated are listed in Table 1. We selected three cultivars adapted to heated greenhouse conditions (Bentley, Felicitas, and Orangela), three cultivars adapted to unheated protected culture (Sprinter, Moonset, and Sympathy), and four cultivars adapted to open field production (Karma, Karisma, Orange Blaze, and Early Sunsation). We refer to these groups as high-tech, lowtech, and field cultivars, respectively. In each group, cultivars with red, yellow, and orange mature color were selected. In 2015 and 2016, all 10 cultivars were compared, but in 2017 , Moonset, Orangela, and Sympathy were omitted from the experiment because these cultivars were no longer commercially available.

Experiments were conducted at the University of New Hampshire Agricultural Experiment Station Woodman Horticultural Research

\begin{tabular}{llll}
\hline $\begin{array}{l}\text { Units } \\
\text { To convert U.S. to SI, } \\
\text { multiply by }\end{array}$ & U.S. unit & SI unit & $\begin{array}{l}\text { To convert SI to U.S., } \\
\text { multiply by }\end{array}$ \\
\hline $\mathrm{l}$ & $\mathrm{cbar}$ & $\mathrm{kPa}$ & $\mathrm{l}$ \\
0.3048 & $\mathrm{ft}$ & $\mathrm{m}$ & 3.2808 \\
2.54 & inch $(\mathrm{es})$ & $\mathrm{cm}$ & 0.3937 \\
1.1209 & $\mathrm{lb} / \mathrm{acre}$ & $\mathrm{kg} \cdot \mathrm{ha}^{-1}$ & 0.8922 \\
0.0254 & $\mathrm{mil}(\mathrm{s})$ & $\mathrm{mm}$ & 39.3701 \\
28.3495 & $\mathrm{Oz}$ & $\mathrm{g}$ & 0.0353 \\
1 & $\mathrm{ppm}$ & $\mathrm{mg} \cdot \mathrm{L}^{-1}$ & 1 \\
$\left({ }^{\circ} \mathrm{F}-32\right) \div 1.8$ & ${ }^{\circ} \mathrm{F}$ & ${ }^{\circ} \mathrm{C}$ & $\left({ }^{\circ} \mathrm{C} \times 1.8\right)+32$
\end{tabular}


Table 1. Pepper cultivars evaluated in high tunnel experiments in 2015, 2016, and 2017 at Durham, NH.

\begin{tabular}{|c|c|c|c|c|c|}
\hline Cultivar & Mature fruit color & Type $^{\mathrm{z}}$ & Seed source ${ }^{\mathrm{y}}$ & Developer $^{\mathrm{x}}$ & Years evaluated \\
\hline Early Sunsation & Yellow & Field & Harris & Seminis & $2015,2016,2017$ \\
\hline Karisma & Red & Field & Harris & HM Clause & $2015,2016,2017$ \\
\hline Karma & Red & Field & Harris & HM Clause & $2015,2016,2017$ \\
\hline Moonset & Yellow & Low-tech & JSS & Enza Zaden & 2015,2016 \\
\hline Sprinter & Red & Low-tech & JSS & Enza Zaden & $2015,2016,2017$ \\
\hline Sympathy & Orange & Low-tech & JSS & Rijk Zwaan & 2015,2016 \\
\hline
\end{tabular}

${ }^{\mathrm{z}}$ As reported by seed source, type indicates the production environment recommended for each cultivar. High-tech = heated greenhouses; low-tech $=$ unheated high tunnels; field = open field culture.

yJSS = Johnny's Selected Seeds (Albion ME); Harris = Harris Seeds (Rochester NY).

${ }^{x}$ Enza Zaden (Enkhuizen, The Netherlands), HM Clause (Davis CA), Rijk Zwaan (De Lier, The Netherlands), Seminis (St. Louis MO), Syngenta (Basel, Switzerland).

Farm in Durham, $\mathrm{NH}\left(\right.$ lat. $43^{\circ} 15^{\prime} \mathrm{N}$, long. $\left.70^{\circ} 93^{\prime} \mathrm{W}\right)$. The site is on Charlton fine sandy loam (coarse loamy, mixed, superactive, mesic Typic Dystrudepts) (U.S. Department of Agriculture, 2016). Experiments were conducted in a $30 \times 60-\mathrm{ft}$ gothic-style unheated high tunnel (Ledgewood Farm Greenhouses, Moultonborough, $\mathrm{NH}$ ) covered with one layer of 4-year, 6-mil infraredretaining (IR) plastic (K50-IR; Klerk's Plastic Products Manufacturing, Richburg, SC). The tunnel was equipped with manual roll-up sides and automatic ventilation fans set to operate when interior temperatures exceeded $75{ }^{\circ} \mathrm{F}$. In the spring and fall, the roll-up sides were closed each night when temperatures were predicted to fall below $50{ }^{\circ} \mathrm{F}$. Once nighttime temperatures consistently stayed above $50{ }^{\circ} \mathrm{F}$, the sides were permanently raised for the summer and closed only briefly during storm events.

Each season, the tunnel was prepared by rototilling, fertilizing, and forming raised beds using a small tractor-mounted bed former with 36 -inch black plastic mulch and a single line of drip tape (12-inch emitter spacing) placed slightly off-center in each row. Weeds between rows were controlled by hand weeding. Plants were transplanted by hand into single rows to create final spacing of 12 inches between plants and $\mathbf{5 5}$ inches between rows. The experimental design was a randomized complete block design with four replications of $10(2015,2016)$ and 7 (2017) cultivars, with six plants per experimental unit and two guard plants at both ends of each row.
Plants were seeded on 30 Mar. 2015, 10 Mar. 2016, and 30 Mar. 2017. Seeds were germinated in a climatecontrolled greenhouse in soilless potting mix (Pro-Mix BX; Pro-Mix, Quakertown, PA) and seedlings were transplanted into 36-cell trays at the cotyledon stage. Beginning 1 to 2 weeks after transplanting, plants were fertilized with $15 \mathrm{~N}-2.2 \mathrm{P}-12.5 \mathrm{~K}$ water-soluble fertilizer (Peters Professional 15-5-15 Cal-Mag; Everris Intl., Geldermalsen, The Netherlands) at a rate of $300 \mathrm{ppm}$ nitrogen $(\mathrm{N})$ weekly. Plants were transplanted into the unheated high tunnel on 28 May 2015, 18 May 2016, and 20 May 2017. Soil moisture was monitored with two tensiometers installed 2 to 4 inches from the drip line in the center of the plant row. Plants were irrigated when the soil water tension at a depth of 6 inches exceeded $20 \mathrm{kPa}$. This generally resulted in irrigation for 2 to $3 \mathrm{~h}$ two to three times per week throughout the growing season.

Each year, we applied $50 \mathrm{lb} /$ acre $\mathrm{N}$ and $124 \mathrm{lb} /$ acre potassium before planting, and another $50 \mathrm{lb} /$ acre $\mathrm{N}$ in a single sidedress application after first fruit set. Preplant fertilizers were broadcast uniformly across the soil surface and incorporated into the soil before planting, and sidedress fertilizers were applied by hand by reaching under the plastic mulch in a circle $\approx 6$ inches from the base of each plant. In 2015 , we applied $13 \mathrm{~N}-0 \mathrm{P}-0 \mathrm{~K}$ organic blended fertilizer (Naturesafe 13-0-0; Darling Ingredients, Chicago, IL) at a rate of $372 \mathrm{lb} /$ acre and sulfate of potash magnesia $(0 \mathrm{~N}-0 \mathrm{P}-18.6 \mathrm{~K}$; Fertrell, Bainbridge, PA) at a rate of $680 \mathrm{lb} /$ acre before bed formation. In 2016 and 2017, we applied soybean meal (7N-0.9P-1.7K; Blue Seal, Muscatine, IA) at a rate of $714 \mathrm{lb} /$ acre and sulfate of potash magnesia at a rate of $665 \mathrm{lb} /$ acre before bed formation. In all 3 years, a sidedress application of $13 \mathrm{~N}-0 \mathrm{P}-0 \mathrm{~K}$ was applied at a rate of $372 \mathrm{lb} /$ acre.

Plants were pruned using a modified version of the "Spanish" trellis system described in detail by Jovicich et al. (2004). Following this system, four main branches were selected and maintained for each plant. To encourage plant growth to support larger crop yields, fruit that formed at the first and second nodes were removed from plants. Plant canopies were supported by twine that ran parallel to the ground on either side of each plot and looped around vertical poles placed between each plot (e.g., every six plants). Approximately five layers of twine were added throughout the growing season, $\approx 6$ to 8 inches apart. In 2015 and 2016, plants were continuously pruned every 1 or 2 weeks throughout the growing season to maintain exactly four leaders. This required moderate weekly pruning through mid-August, followed by light biweekly pruning after midAugust. In 2017, for 2 weeks after selecting the four initial leaders, plants were pruned weekly to maintain those leaders, and then side shoots were allowed to develop.

Plants were scouted weekly for insect pests, and biological controls were used to manage aphids (family Aphididae) and tobacco hornworms (Manduca sexta). Foliar applications of Bacillus thuringiensis (Dipel; Valent Biosciences, Libertyville, IL) were applied at label rates once in 2015 and 2017 to control tobacco hornworm, 
Table 2. Fruit size and cumulative yields of marketable mature colored bell pepper fruit from plants grown in high tunnels in 2015, 2016, and 2017 at Durham, NH.

\begin{tabular}{|c|c|c|c|c|c|c|c|c|c|}
\hline \multirow[b]{2}{*}{ Cultivar } & \multicolumn{3}{|c|}{ Mean fruit size $(g)^{z}$} & \multicolumn{3}{|c|}{ Marketable fruit (no./plant) } & \multicolumn{3}{|c|}{ Marketable yield (g/plant) } \\
\hline & 2015 & 2016 & 2017 & 2015 & 2016 & 2017 & 2015 & 2016 & 2017 \\
\hline Bentley & 276 & 231 & 244 & $8.3{b c^{y}}^{y}$ & $8.0 \mathrm{~b}$ & $7.2 \mathrm{bc}$ & $2285 \mathrm{a}$ & 1839 & $1749 \mathrm{~b}$ \\
\hline Felicitas & 283 & 290 & 267 & $7.9 \mathrm{bcd}$ & $6.1 \mathrm{~b}$ & $8.8 \mathrm{~b}$ & $2229 \mathrm{a}$ & 1774 & $2358 \mathrm{a}$ \\
\hline Karisma & 316 & 290 & 322 & $5.4 \mathrm{~d}$ & $5.8 \mathrm{~b}$ & $5.6 \mathrm{c}$ & $1713 \mathrm{ab}$ & 1691 & $1800 \mathrm{~b}$ \\
\hline Karma & 311 & 301 & 248 & $6.0 \mathrm{~cd}$ & $5.5 \mathrm{~b}$ & $6.3 \mathrm{bc}$ & $1856 \mathrm{ab}$ & 1657 & $1566 \mathrm{~b}$ \\
\hline Orangela & 238 & 226 & - & $8.9 \mathrm{~b}$ & $8.0 \mathrm{~b}$ & - & $2119 \mathrm{ab}$ & 1818 & - \\
\hline Sprinter & 248 & 226 & 229 & $7.1 \mathrm{bcd}$ & $5.3 \mathrm{~b}$ & $6.8 \mathrm{bc}$ & $1768 \mathrm{ab}$ & 1194 & $1557 \mathrm{~b}$ \\
\hline Sympathy & 247 & 233 & - & $8.0 \mathrm{bcd}$ & $5.5 \mathrm{~b}$ & - & $1969 \mathrm{ab}$ & 1292 & - \\
\hline Significance & & & & $* * *$ & $* * *$ & $* * *$ & ** & NS & $* * *$ \\
\hline
\end{tabular}

${ }^{\mathrm{z}}$ Mean fruit size $=$ marketable yield $($ grams $) /$ marketable fruit $($ number $) ; \mathrm{l} g=0.0353 \mathrm{oz}$.

'Within a column, means followed by the same letter are not significantly different at $P \leq 0.05$ using Tukey's honestly significant difference test.

${ }^{\mathrm{x}}$ Cultivar not included in this experiment.

Ns, ${ }^{* *},{ }^{* *}$ Not significant or significant at $P \leq 0.01$ or 0.001 , respectively.

and common green lacewing larvae (Chrysoperla carnea) were released twice in 2015 and once in 2016 to control aphid populations.

All ripe fruit (those showing at least $10 \%$ mature red, yellow, or orange color) were harvested weekly. Marketable and cull fruit from each plot were counted and weighed. Cull fruit were those deemed unmarketable because they showed sunscald, blossom end rot, or alternaria fruit rot (Alternaria alternata) or if they were badly misshapen. The frequency of unmarketable fruit was calculated by dividing the number of cull fruit by the number of all cull and marketable fruit. Just before the final harvest, plant height was measured from the soil line to the tallest meristem for each plot. At the final harvest 21 Oct. 2015, 25 Oct. 2016, and 13 Nov. 2017), all fruit were stripped from the plants and sorted into ripe, mature green, and immature green categories.

The effects of cultivar on all dependent variables were analyzed by analysis of variance (ANOVA) using JMP Pro software (version 13; SAS Institute, Cary, NC). In overall ANOVAs conducted using the 10 cultivars evaluated in 2 years, and the seven cultivars evaluated in all 3 years, significant cultivar $\times$ year interactions were detected for some variables (marketable number of fruit and percent unmarketable fruit). For this reason, data from the 3 years were analyzed and are presented separately. Frequency data (e.g., frequency of unmarketable fruit) were arcsine-transformed before performing ANOVA. When the overall $\mathrm{F}$ test was significant $(P \leq 0.05)$, differences between treatments were evaluated using Tukey's honestly significant difference tests at $P \leq 0.05$. To specifically make comparisons between high-tech, low-tech, and field cultivars, marketable yield data were analyzed using the general linear models procedure using orthogonal contrasts.

\section{Results}

Nearly all cultivars evaluated produced large blocky bell peppers averaging $>230 \mathrm{~g} /$ fruit (Table 2). Two cultivars, Karma and Karisma, produced fruit weighing $>300 \mathrm{~g}$ in 2 of 3 years. In contrast, 'Orange Blaze' produced small but thick-walled fruit that usually only had two or three lobes, averaging slightly more than 100 g per fruit. Photographs of representative fruit of all cultivars are provided in Fig. 1. Slight differences in fruit shape were apparent, but all cultivars produced attractive marketable fruit.

The small-fruited cultivar Orange Blaze consistently produced the greatest number of marketable fruit per plant in all 3 years (Table 2 ). The large-fruited cultivar Karisma produced the fewest marketable fruit in 2015 and 2017 but not significantly fewer than several other cultivars.

Marketable yields (cumulative marketable weight per plant) ranged from 1576 to $2285 \mathrm{~g} /$ plant in 2015 , from 1194 to $1839 \mathrm{~g} /$ plant in 2015 , and 1471 to $2358 \mathrm{~g} /$ plant in 2017 (Table 2). Significant differences in marketable yield between cultivars existed only in 2015 and 2017 (Table $2)$. In both of these years, the smallfruited 'Orange Blaze' produced the lowest marketable yield of fruit, significantly less than 'Bentley' and 'Felicitas' in 2015, and significantly less than 'Felicitas' in 2017.

Specific contrasts comparing hightech, low-tech, and field cultivars revealed that the high-tech cultivars produced significantly greater marketable yields in all 3 years $(P<0.0001)$ than the low-tech or field cultivars. In all 3 years, the high-tech cultivars Bentley and Felicitas produced among the top three marketable yields, as did Orangela in the 2 years it was evaluated. Yields for low-tech cultivars did not differ significantly from field cultivars, regardless of whether the small-fruited Orange Blaze was included in the analysis.

Plant height was measured as an indication of overall vigor of each cultivar. In general, plants grew more vigorously in 2015 and 2016 than in 2017 , with the tallest plants at the end of the 2015 and 2016 seasons reaching heights nearly double those measured in 2017 (Table 3). In 2015, 'Orangela' was the tallest cultivar at $145.7 \mathrm{~cm}$ high, significantly taller than Bentley, Karisma, Karma, and Moonset. In 2016, the cultivar Sprinter was the tallest at $140 \mathrm{~cm}$ high, significantly taller than Early Sunsation, Karisma, Karma, and Moonset. In 2017, no significant 


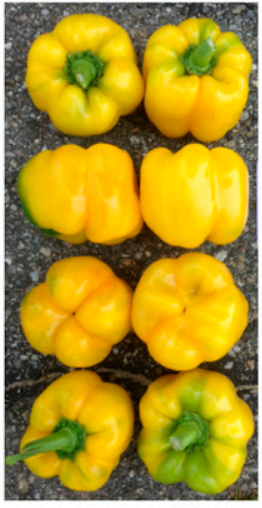

Bentley

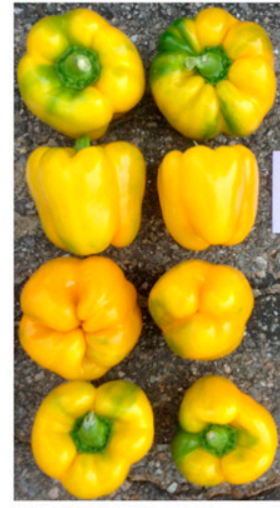

Early Sunsation

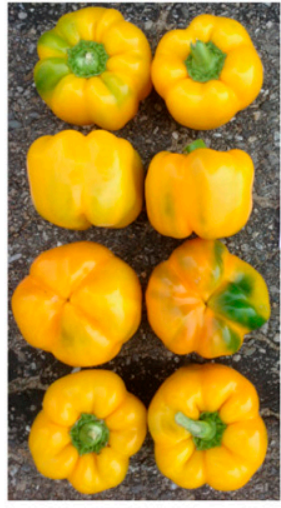

Moonset

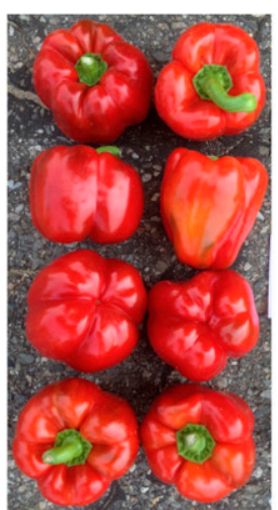

Felicitas

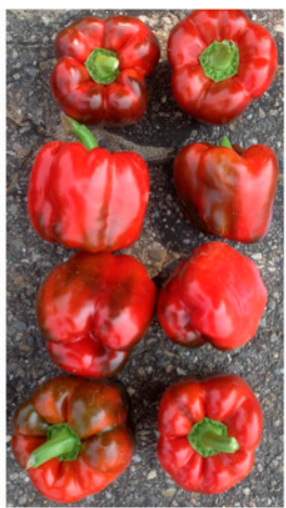

Karisma

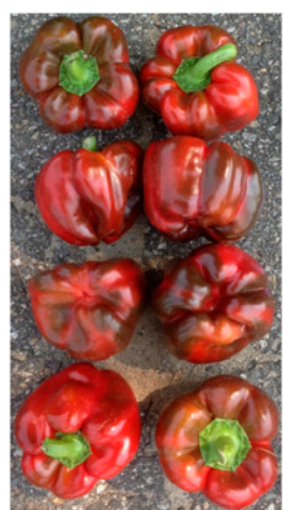

Karma

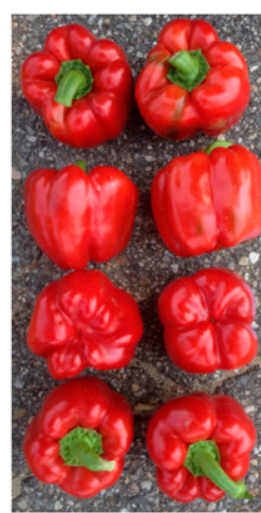

Sprinter

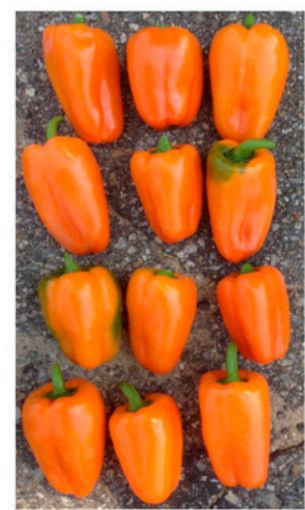

Orange Blaze

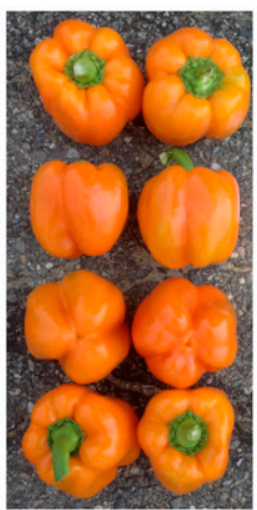

Orangela

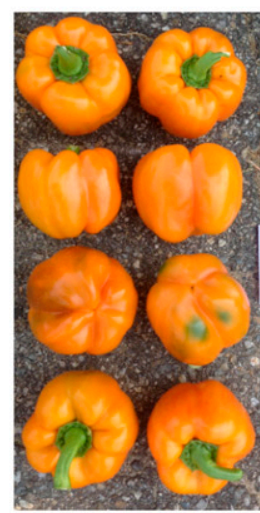

Sympathy

Fig. 1. Representative mature colored fruit from all bell pepper cultivars evaluated in Durham, NH, in 3 years $(2015,2016$, and 2017).

differences existed between cultivars, but all plants were shorter than in previous years, ranging from only 59 to $77 \mathrm{~cm}$ high.

At the final harvest of each season when all mature green fruit and immature fruit were removed from each plant, there were no significant differences among cultivars in the total weight of mature green fruit in any year (Table 3). Immature green fruit were counted in 2015 and 2017 and were weighed in 2016 and 2017, and immature green fruit represented a wide range of sizes and weights. Significant differences in immature green fruit production between cultivars were not observed in any year (data not shown).

The percentage of unmarketable fruit differed significantly between cultivars in all 3 years (Table 4). The majority of fruit categorized as unmarketable exhibited sunscald or blossom end rot (BER), two disorders that are difficult to distinguish (data not shown). The cultivar Karisma produced the highest percentage of unmarketable fruit in both 2015 $(30.3 \%)$ and 2017 (24.7\%)-significantly higher than Bentley (3.8\%) and Orangela (5.7\%) in 2015 , and significantly higher than all other cultivars except Sprinter (13.4\%) in 2017. In 2016, the cultivars Early Sunsation $(32.1 \%)$ and Sprinter $(33.1 \%)$ produced the highest percentage of unmarketable fruit, significantly higher than Bentley (5.2\%).

To evaluate seasonal production patterns, cumulative yields over 2-week time intervals were calculated and presented (Fig. 2). In all years, all cultivars showed a single early peak of production between 159 and 175 d after seeding. 'Bentley' peaked slightly earlier than most other cultivars in 2015 and 2017. 'Karisma' (in 2016 and 2017), and 'Felicitas' and 'Early Sunsation' in 2017, peaked slightly later than other cultivars. At the end of the growing season in all 3 years, relatively large amounts of mature green fruit were harvested from all cultivars.

\section{Discussion}

In the northeastern United States, high tunnels that are unheated or minimally heated in the spring are widely used for season extension and to increase yields and quality of warmseason crops like tomato, bell pepper, and eggplant (Solanum melongena). In this study, we measured marketable yields of colored bell peppers in high tunnels, which ranged from 1200 to $2300 \mathrm{~g} /$ plant, depending on year and cultivar. To the best of our knowledge, these are the first data from a multiyear experiment that document colored bell pepper cultivar performance in high tunnels in our region.

Our yields were higher than those reported by other single-year studies: Bogash and Elkner (2011) measured colored fruit yields of 1043 to $1088 \mathrm{~g} /$ plant in high tunnels in Pennsylvania, and Taber et al. (2009) reported high tunnel colored fruit yields in Iowa that corresponded to well below $1000 \mathrm{~g} /$ plant. Our yields are comparable to those reported from minimally heated greenhouses in Florida [1547 to $2548 \mathrm{~g} /$ plant (Jovicich et al., 2004)]. However, in a single-year study in high tunnels in New York, Reid et al. (2011) described yields 

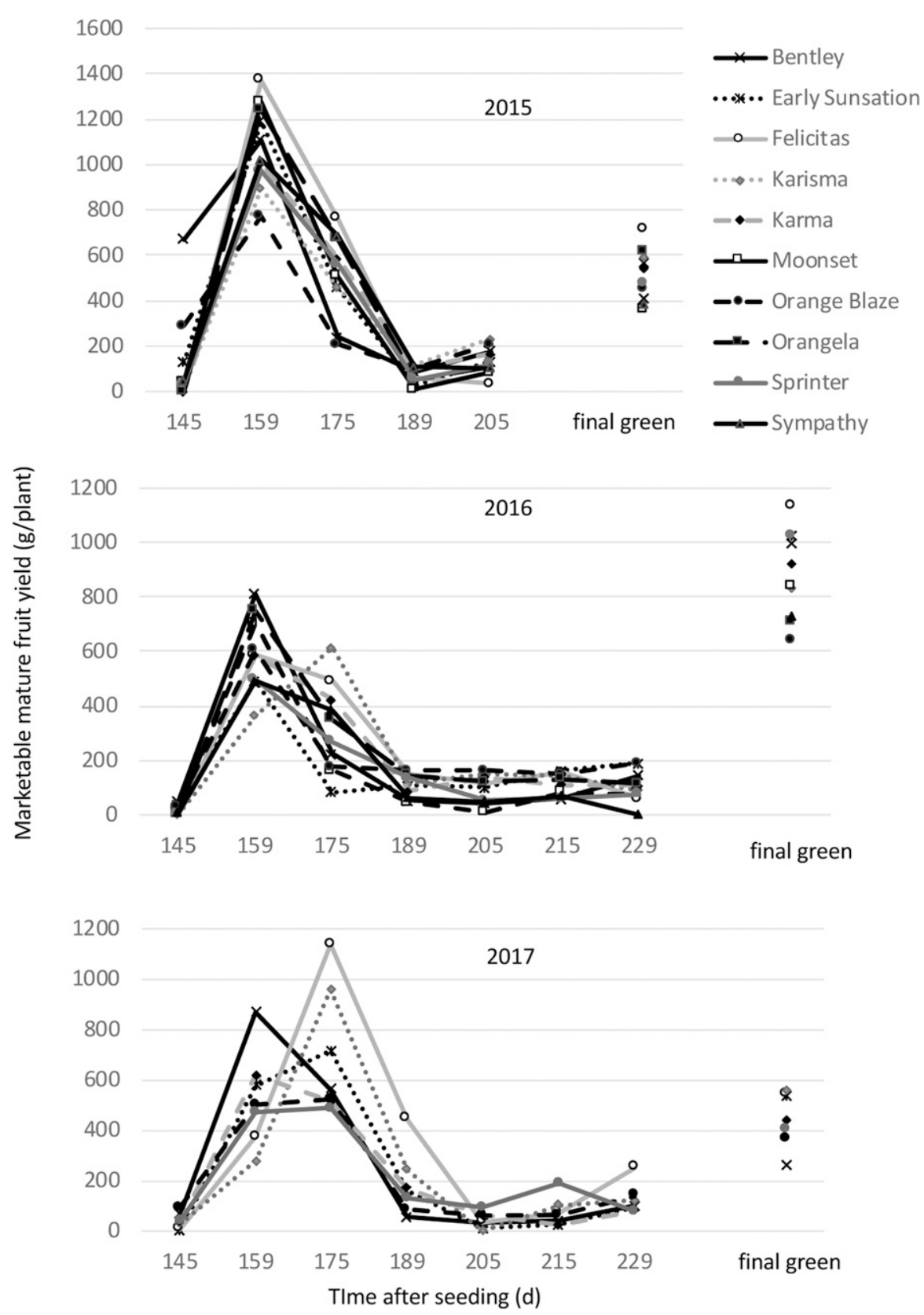

Fig 2. Seasonal production of colored bell peppers grown in a high tunnel in Durham, NH, in 3 years $(2015,2016$, and 2017). Yields for each date represent marketable fruit harvested in the preceding 2 weeks. The unconnected data points on each graph marked "final green" indicate yields of mature green marketable fruit from the final harvest; $1 \mathrm{~g}=0.0353 \mathrm{oz}$.

ranging from 3200 to more than $3900 \mathrm{~g}$ /plant of mature colored bell peppers, suggesting that even higher yields may be possible with different cultivar choice or growing conditions. Certainly, typical yields of fruit for bell pepper in climate-controlled greenhouses in The Netherlands and Canada far exceed these ranges, sometimes exceeding $8000 \mathrm{~g} /$ plant (Jovicich et al., 2005).

Several studies have evaluated green bell pepper production in the field in the northeastern United States. Sanchez et al. (2011) presented yields ranging from 589 to $2450 \mathrm{~g} /$ plant in Pennsylvania; Hutton and Handley (2007) presented yields up to $750 \mathrm{~g} /$ plant in Maine. Further, these studies reported yields for green bell peppers, not for colored fruit, which require additional ripening time and for which we presume yields would have been even lower. Although we did not compare field production with high tunnel production in this study, the low yields of green bell peppers reported in the fieldbased studies described earlier compared with the results presented here suggest that high tunnel production of colored bell pepper likely results in substantial increases in yield over field production.

In 2 of 3 years, we observed moderate percentages of unmarketable fruit in some cultivars; for example, more than $30 \%$ of fruit were unmarketable for the cultivar Karisma. For all cultivars, the majority of fruit categorized as unmarketable exhibited sunscald or BER. Several researchers have demonstrated that fertilization program, cultivar susceptibility, irrigation frequency, and pruning system can all impact BER (Bar-Tal et al., 2001; Coolong et al., 2019; Diaz-Perez and Hook, 2017; Jovicich et al., 2004; Marcelis and Ho, 1999). Thus, altered crop management could potentially mitigate these crop losses. Our study was conducted in amended native soil substrates, as is typical in the region. Although native soil has greater moisture-holding capacity than hydroponic substrates, irrigation events were much less frequent in our study than is required in hydroponic systems, and moisture fluctuations may have been sufficient to promote BER. Our results affirm that BER and sunscald may be important considerations for future studies evaluating bell pepper cultivars for high tunnel production conditions.

We had hypothesized that cultivars developed for protected cultivation would be more likely than field cultivars to exhibit continued steady production throughout the growing season. However, we found that all cultivars showed a peak of fruit production lasting for $\approx 6$ weeks after the first harvest followed by much lower yields for up to 6 additional weeks. Just before frost in all years, a relatively large number of mature green fruit were harvested, suggesting that fruit production may have had a second peak if our growing season were longer. Many researchers have described a cyclic pattern of high and low fruit set for bell pepper, particularly for large-fruited cultivars (Heuvelink et al., 2004; Kato and Tanaka 1971; Wubs et al., 2009), and this is considered a significant problem in greenhouse bell pepper cultivation. Marcelis et al. (2004) demonstrated 
Table 3. Plant height and weight of mature green fruit at final harvest of peppers grown in high tunnels in 2015, 2016, and 2017 at Durham, NH.

\begin{tabular}{|c|c|c|c|c|c|c|}
\hline \multirow[b]{2}{*}{ Cultivar } & \multicolumn{3}{|c|}{ Plant ht $(\mathrm{cm})^{\mathrm{z}}$} & \multicolumn{3}{|c|}{$\begin{array}{l}\text { Mature green fruit wt } \\
(\mathrm{g} / \text { plant })^{\mathrm{z}}\end{array}$} \\
\hline & 2015 & 2016 & 2017 & 2015 & 2016 & 2017 \\
\hline Bentley & $110.2 \mathrm{bc}^{\mathrm{y}}$ & $114.3 \mathrm{abc}$ & 59.1 & 409 & $1001 \mathrm{a}$ & 259 \\
\hline Early Sunsation & $124.5 \mathrm{abc}$ & $104.8 \mathrm{c}$ & 63.2 & 663 & $1023 \mathrm{a}$ & 537 \\
\hline Felicitas & $126.4 \mathrm{abc}$ & $123.2 \mathrm{abc}$ & 75.9 & 712 & $1136 \mathrm{a}$ & 542 \\
\hline Karisma & $113.0 \mathrm{bc}$ & $97.2 \mathrm{c}$ & 66.4 & 592 & $830 \mathrm{a}$ & 558 \\
\hline Karma & $103.8 \mathrm{c}$ & $110.5 \mathrm{bc}$ & 67.6 & 542 & $925 \mathrm{a}$ & 503 \\
\hline Moonset & $110.8 \mathrm{bc}$ & $104.8 \mathrm{c}$ & $-^{x}$ & 365 & $840 \mathrm{a}$ & - \\
\hline Orange Blaze & $133.0 \mathrm{ab}$ & $135.3 \mathrm{ab}$ & 77.5 & 452 & $644 a$ & 368 \\
\hline Orangela & $145.7 \mathrm{a}$ & $136.5 \mathrm{ab}$ & - & 565 & $709 \mathrm{a}$ & - \\
\hline Sprinter & $133.7 \mathrm{ab}$ & $140.3 \mathrm{a}$ & 76.8 & 584 & $1023 \mathrm{a}$ & 401 \\
\hline Sympathy & $132.1 \mathrm{abc}$ & $123.2 \mathrm{abc}$ & - & 389 & 728 a & - \\
\hline Significance & $* * *$ & $* * *$ & NS & NS & * & NS \\
\hline
\end{tabular}

${ }^{\mathrm{z}} 1 \mathrm{~cm}=0.3937$ inch, $\mathrm{lg}=0.0353 \mathrm{oz}$

${ }^{y}$ Within a column, means followed by the same letter are not significantly different at $P \leq 0.05$ using Tukey's honestly significant difference test.

${ }^{x}$ Cultivar not included in this experiment.

NS, ${ }^{*},{ }^{* *}$ Not significant or significant at $P \leq 0.05$ or 0.001 , respectively.

that fruit set in pepper is determined by the source/sink ratio and temperature around the time of anthesis; thus, abundant early fruit set induces abortion of subsequent fruit, probably due to a combination of competition for assimilates and dominance of the early fruit.

Most studies evaluating pepper fruit set patterns have been conducted in controlled greenhouse conditions with plants pruned to two leaders. We used a four-leader system in response

Table 4. Percentage of unmarketable fruit harvested from peppers grown in high tunnels in 2015, 2016, and 2017 at Durham, NH.

\begin{tabular}{lccc}
\hline & \multicolumn{3}{c}{ Unmarketable fruit (\%) } \\
\cline { 2 - 4 } Cultivar & $\mathbf{2 0 1 5}$ & $\mathbf{2 0 1 6}$ & $\mathbf{2 0 1 7}$ \\
\hline Bentley & $3.8 \mathrm{a}^{\mathrm{y}}$ & $5.2 \mathrm{a}$ & $4.8 \mathrm{a}$ \\
Early & $13.7 \mathrm{ab}$ & $32.1 \mathrm{~b}$ & $5.5 \mathrm{a}$ \\
$\quad$ Sunsation & & & \\
Felicitas & $8.8 \mathrm{ab}$ & $10.0 \mathrm{ab}$ & $6.0 \mathrm{a}$ \\
Karisma & $30.3 \mathrm{~b}$ & $22.9 \mathrm{ab}$ & $24.7 \mathrm{~b}$ \\
Karma & $16.4 \mathrm{ab}$ & $15.1 \mathrm{ab}$ & $6.9 \mathrm{a}$ \\
Moonset & $12.6 \mathrm{ab}$ & $10.2 \mathrm{ab}$ & $-{ }^{\mathrm{x}}$ \\
Orange Blaze & $22.7 \mathrm{ab}$ & $16.8 \mathrm{ab}$ & $2.8 \mathrm{a}$ \\
Orangela & $5.7 \mathrm{a}$ & $11.4 \mathrm{ab}$ & - \\
Sprinter & $18.3 \mathrm{ab}$ & $33.3 \mathrm{~b}$ & $13.4 \mathrm{ab}$ \\
Sympathy & $8.9 \mathrm{ab}$ & $9.0 \mathrm{ab}$ & - \\
Significance & $*$ & $* *$ & $* *$ \\
\hline Un *
\end{tabular}

${ }^{\mathrm{z}}$ Unmarketable fruit included those damaged by sunscald, blossom end rot, or alternaria fruit rot.

${ }^{y}$ Within a column, means followed by the same letter are not significantly different at $P \leq 0.05$ using Tukey's honestly significant difference test.

${ }^{x}$ Cultivar or factor not included in this experiment.

*, ** Significant at $P \leq 0.05$ or 0.01 , respectively. to studies showing that more severe pruning strategies ("V-trellis" compared with the "Spanish" system) for greenhouse pepper resulted in high levels of BER and lower marketable yields (Jovicich et al., 2004). Increasing the number of leaders increases the potential number of early fruit set; which could presumably inhibit subsequent flower set. Thus, we suspect that our four-leader system permitted a larger fruit set than two leaders would have allowed, but at the expense of later fruit set. In the last year of our study, we did less late-season pruning, which probably resulted in more leaders. This may have been a significant contributing factor to the reduced height of plants observed in 2017 compared with 2015 and 2016. Additional work is needed to determine the optimal system for training and pruning peppers in high tunnels in the northeastern United States.

Given the single peak of colored fruit production that we observed, it may not be worthwhile for producers to maintain individual pepper plantings for a long production season. If growers have alternative late spring or early fall uses for high tunnels, establishing multiple staggered plantings of pepper in high tunnels may optimize profits. This takes advantage of large quantities of pepper fruit during the early peak production, then allowing removal of the plants to make way for other crops. Heuvelink et al. (2004) made a similar observation and suggested that delaying planting for part of a greenhouse, particularly for late spring plantings, can help make the whole greenhouse production more consistent.

In conclusion, nearly all bell pepper cultivars evaluated produced good yields of high-quality colored fruit in a high tunnel in New Hampshire using a four-leader pruning system. Of the 10 cultivars we evaluated, those developed for controlled environments produced higher marketable yields than those developed for field or unheated tunnels. However, in all 3 years, we observed a single peak in production that lasted for $\approx 6$ weeks regardless of cultivar. Thus, growers should choose cultivars with fruit that is desirable to their markets, and they should consider staggering plantings to maximize yields.

\section{Literature cited}

Bar-Tal, A., M. Keinan, B. Aloni, L. Karni, Y. Oserovitz, S. Gantz, A. Hazan, M. Itach, N. Tratakovski, A. Avidan, and I. Posalski. 2001. Relationships between blossom-end rot and water availability and Ca fertilization in bell pepper fruit production. Acta Hort. 554:97-104.

Bogash, S. and T. Elkner. 2011. Final report-Colored bell pepper high tunnel variety trial 2011.26 Feb. 2020. <http:// www.paveggies.org/wp-content/ uploads/research-report-2011-15-hightunnel-colored-bell-pepper-variety-trial. pdf $>$

Carey, E.E., L. Jett, W.J. Lamont, Jr., T.T. Nennich, M.D. Orzolek, and K.A. Williams. 2009. Horticultural production in high tunnels in the United States: A snapshot. HortTechnology 19:37-43.

Coolong, T., A.L.B.R. da Silva, and J. Shealey. 2019. Fertilizer program impacts yield and blossom end rot in bell pepper. HortTechnology 29:163-169.

Diaz-Perez, J.C. and J.E. Hook. 2017. Plastic-mulched bell pepper (Capsicum annumm L.) plant growth and fruit yield and quality as influenced by irrigation rate and calcium fertilization. HortScience 52:774-781.

Fitzgerald, C. and M. Hutton. 2012. Production practices and challenges with high tunnel systems in Maine. J. Natl. Assoc. County Agr. Agents 5(2). 18 Mar. 2020. <https://www.nacaa.com/ journal/index.php?jid $=170>$.

Heuvelink, E., O. Körner, and L.F.M. Marcelis. 2004. How to reduce yield 
fluctuations in sweet pepper? Acta Hort. 633:349-355.

Hutton, M.G. and D.T. Handley. 2007. Bell pepper cultivar performance under short, variable growing seasons. HortTechnology 17:136-141.

Jovicich, E., D.J. Cantliffe, and P.J. Stoffella. 2004 . Fruit yield and quality of greenhousegrown bell pepper as influenced by density, container, and trellis system. HortTechnology 14:507-513.

Jovicich, E., J.J. VanSickle, D.J. Cantliffe, and P.J. Stoffella. 2005. Greenhousegrown colored peppers: A profitable alternative for vegetable production in Florida? HortTechnology 15:355-369.

Kato, T. and M. Tanaka. 1971. Studies on the fruit setting and development of sweet peppers. I. Fruiting behavior. J. Jpn. Soc. Hort. Sci. 40:359-366.

Marcelis, L., E. Heuvelink, L.R. Baan Hofman-Eijer, J. Den Makker, and L.B. Xue. 2004. Flower and fruit abortion in sweet pepper in relation to source and sink strength. J. Expt. Bot. 55:2261-2268.

Marcelis, L.F.M. and L.C. Ho. 1999. Blossom-end rot in relation to growth rate and calcium content in fruits of sweet pepper (Capsicum annumm L.). J. Expt. Bot. 50:357-363.

Maynard, E.T. and I.S. Calsoyas. 2015. Mini sweet pepper and heirloom pepper performance in high tunnels, 2015. 26 Feb. 2020. <https://ag.purdue.edu/ hla/fruitveg/MidWest\%20Trial\% 20Reports/2015/05-01_Maynard_ Pepper.pdf $>$.

Reid, J., K. Klotzbach, and N. Hoover. 2011. High tunnel pepper variety trial, 2011. 26 Feb. 2020. <https://rvpadmin. cce.cornell.edu/uploads/doc_3.pdf $>$.

Sanchez, E.S., T.M. Butzler, S.M. Bogash, T.E. Elkner, R.E. Osterling, M.D. Orzolek, and L.J. Stivers. 2011. Pennsylvania statewide bell pepper cultivar evaluation. HortTechnology 21:384-390.
Sideman, B., H. Bryant, M. Skinner, C.F. Sullivan, M. Hutton, B. Hoskins, and E. Sideman. 2016. Survey of high tunnel practices in northern New England. 9 Mar. 2020. <https://hightunneltomatoproject. files.wordpress.com/2016/12/surveyresults. pdf>.

Taber, H.G., N.P. Howell, and B.J. Havlovic. 2009. High tunnel colored pepper production. Iowa State Res. Farm Progr. Rep. 463. 26 Feb. 2020. <http:// lib.dr.iastate.edu/farms_reports/463>.

U.S. Department of Agriculture. 2016. Official soil series descriptions: Charlton Series. 26 Feb. 2020. <https://soilseries. sc.egov.usda.gov/OSD_Docs/C/ CHARLTON.html>.

Wells, O.S. 1996. Rowcover and high tunnel growing systems in the United States. HortTechnology 6:172-176.

Wubs, A.M., M. Yuntao, L. Hemerik, and E. Heuvelink. 2009. Fruit set and yield patterns in six Capsicum cultivars. HortScience 44:1296-1301. 